\title{
Peristiwa Tutur dalam Prosesi Selamatan Laut di Desa Tanjung Luar Lombok
}

\author{
Ri'ina $^{1}$, Hary Murcahyanto ${ }^{2}$, Muh. Jaelani Al-Pansori ${ }^{3}$ \\ Universitas Hamzanwadi, \\ ${ }^{1}$ riina@yahoo.com, ${ }^{2}$ harymurcahyanto@gmail.com, ${ }^{3}$ jaelan_alpan@yahoo.com
}

\begin{abstract}
Abstrak
Penelitian ini bertujuan menganalisis Peristiwa Tutur dalam Prosesi Selamatan Laut di Desa Tanjung Luar, Kabupaten Keruak, Lombok. Responden dalam penelitian ini adalah orang-orang lokal yang masih percaya pada kekuatan magis prosesi yang diadakan setahun sekali sebagai bentuk penghormatan kepada masyarakat Tanjung Luar karena mereka telah diberkati dengan lautan luas tempat di mana hidup mereka bergantung. Metode dalam penelitian ini menggunakan metode deskriptif kualitatif. Data diperoleh, dianalisis dengan teknik analisis data. Hasil penelitian menyimpulkan bahwa ada acara pidato dan tindak tutur dalam prosesi selamatan laut, yaitu dari awal pembukaan program hingga akhir proses Tikolok sehingga menciptakan kesan yang sangat mendalam bagi masyarakat Tanjung. Luar menjaga tradisi nenek moyang. Bahasa yang digunakan dalam acara prosesi salah satunya adalah; Lamun kau teqa lamun kau darat! Kaming kalopah, suram anung rajane (Saya tidak suka menerima utusan dan perintah, jika rajamu adalah rajamu yang mengutusmu. Panggil rajamu!). Kalimat Perintah, diikuti oleh tindakan, sehingga dapat digolongkan sebagai tindak tutur.
\end{abstract}

Kata Kunci: Masyarakat, Selamatan Laut, Tindak Tutur

\section{PENDAHULUAN}

Bahasa sangat erat hubungannya dengan kehidupan manusia, sebab dalam kehidupan manusia bahasa memiliki peranan penting. Peranan penting bahasa adalah sebagai alat komunikasi antara pembicara dengan pendengar atau antara penulis dengan pembaca melalui inilah bahasa. Tindak tutur dan peristiwa tutur yang dilakukan manusia dalam kehidupan bermasyarakat dipengaruhi oleh berbagai latar belakang yang bervariasi yang disebut dengan konteks tutur. Selain itu juga tindak tutur dilakukan dengan tujuan yang beragam diantaranya adalah untuk menjelaskan, memohon, mendukung, mengungkapkan perasaan, menjanjikan, menyarankan maupun mengkritik orang lain. Adapun peristiwa tutur, memiliki perbedaan dengan tindak tutur, karena peristiwa tutur merupakan tutur yang terjadi melalui komunikasi dengan topik satu arah pada tempat dan situasi tertentu. Peristiwa tutur maupun tidak tutur bisa 
kita lihat di masyarakat Tanjung Luar, yang biasa ditemui di Pasar Ikan Tanjung Luar, disana akan terjadi tawar menawar pembeli dengan pedagang. Tak hanya itu kondisi ril masyarakat yang senang hidup bergerombol pada malam harinya memiliki daya tarik sendiri karena dari tuturan mereka terdapat peristiwa tutur. Sehingga mereka tidak bisa lepas dari sistem keakrabatan. Terjadinya interaksi yang terus-menerus menjadikan mereka hidup damai walaupun harus berdampingan dengan suku yang berbeda. Perbedaan bahasa daerah juga, tidak menjadikan mereka menutup diri dari dunia sekitarnya justru hal itu menjadi nilai yang luhur karena mereka saling menghargai dan mempelajari bahasa daerah secara tidak langsung.

Desa Tanjung Luar merupakan destinasi budaya Selamatan Laut atau Nyalamak Dilau dalam bahasa Bajaunya. Nyalamak Dilau merupakan tradisi yang di wariskan dari generasi kegenerasi sehingga sampai saat ini menjadi ritual tahunan, yang di tetapkan oleh pemerintah. Menurut sebagian masyarakat Tanjung Luar, prosesi Selamatan Laut ini adalah bentuk rasa syukur mereka kepada Tuhan yang Maha Esa, karena telah dikaruniakan kekayaan laut, yang tidak pernah sepi dari ikan. Acara ini bukanlah kesyirikan, tetapi simbol rasa syukur atas kekayaan Laut, tempat mereka bergantung hidup.
Nyelamak Dilau, ini sebagai pengharapan agar hasil tangkapan mereka meningkat melalui prosesi yang digelar masyarakat keturunan Suku Bajo, Mandar, Makasar dan Suku Bugis tersebut sudah berlangsung sejak 400 tahun silam.

Penggelaran acara ini membutuhkan persiapan yang cukup panjang, karena acara tersebut terhitung cukup besar yang berlangsung selama tiga belas hari, tiga belas malam pada dasarnya menurut Daeng Abas sebagai mangku adat di Desa Tanjung Luar. Yang paling di tuntut pada acara ini adalah bagaimana kesiapan Sandro sebagai pemandu acara? Ada dua Sandro pada acara ini, Sandro pertama berada di darat, yang dimana Sandro ini adalah seorang perempuan yang miss komunikasi pada siapapun sampai acara itu selesai, namun ia menggunakan bahasa isyarat, dan apabila Sandro perempuan berbicara, maka gagallah acara Selamatan Laut yang sedang di gelar itu. Sedangkan Sandro laki-laki tempatnya di Laut, dan bisa juga berada di darat sesekali waktu. Sandro ini berkomunikasi ketika ada dari warga yang kesurupan, disanalah kemampuan berbahasa Sandro di uji, karena orang yang kesurupan atau kemasukan Jin biasanya menggunakan bahasa sukunya masing-masing. Yang menarik pada acara tersebut, yaitu; adanya tuturan yang dilakukan oleh Sandro pada 
waktu tertentu, yang biasa kita sebut dengan peristiwa tutur.

Peristiwa tutur dan tindak tutur adalah kegiatan yang menggunakan bahasa sebagai sarana dasar untuk mengungkapkan ide, sasaran, pendapat, perasaan maupun dukungan kepada orang lain secara tulisan. Tuturan yang terjadi di Pasar Tanjung Luar misalnya tergolong sebagai peristiwa tutur dan tindak tutur karena ada perckapan satu arah oleh pembeli dan pembaca dan tindak tutur karena ada interkasi yang diiring perbuatan. Adapun alasannya adalah tindak tutur an-tuturan tersebut dipengaruhi oleh peristiwa-peristiwa yang terjadi di sekitar masyarakat, sehingga dilingkupi oleh berbagai konteks tutur; topik-topik tuturanya tidak terbatas pada masalah-masalah tertentu, sehingga memiliki daya kreatifitas yang tinggi; tuturan tersebut diciptakan dengan tujuan dan jenis yang beranekaragam, sehingga tidak menonton dan tidak membosankan; sehingga menimbulkan perasaan senang.

Dalam hal ini peneliti bermaksud meneliti peristiwa tutur pada prosesi Selamatan Laut di Desa Tanjung Luar Kecamatan Keruak. Contoh peristiwa tutur pada acara tersebut, yaitu; "Eee... kurang neje Datok?" (ada kurangnya Datok?), kata salah satu masyarakat yang kesurapan menggunakan bahasa Bugis. "apa kurangnya Datok?” tanya Sandro. "Ee..e..!" kata orang yang kesurupan. "gih". Jawab Sandro, kemudian menambah sesajian yang dimaksudkan oleh orang yang kesurupan.

Percakapan singkat di atas yang dilakukan oleh Sandro dan orang yang kesurupan merupakan peristiwa tutur karena adanya pokok pembicaraan yang fokus pada satu topik pembicaraan, yaitu; kurangnya sesajian dalam prosesi Selamatan Laut. Selain itu juga percakan tersebut terjadi pada waktu tertentu atau situasi tertentu, yaitu; pada prosesi selamatan laut berlangsung. Hal ini tentu saja menarik untuk diteliti.

Permasalahan dalam penelitian ini mengkaji tentang Peristiwa Tutur dalam Prosesi Selamatan Laut di Desa Tanjung Luar Kecamatan Keruak. Adapun tujuan penelitian ini adalah untuk mengetahui bentuk peristiwa tutur dan tindak tutur yang terdapat dalam prosesi Nyelamak Dilau atau tradisi masyarakat Tanjung Luar yang dilaksanakan satu tahun sekali. adapun teori-teori yang digunakan dalam penelitian ini, yaitu peristiwa tutur dan tindak tutur.

\section{KAJIAN TEORI}

Peristiwa tutur merupakan terjadinya komunikasi timbal balik antara penutur dan mitra tutur pada satu tempat dengan 
satu pokok pembicaraan. Peristiwa tutur bisa terjadi dimana saja dan kapan saja sehingga hal itu menjadi rutinitas harian. Peristiwa tutur adalah terjadinya atau berlangsungnya interaksi linguistik dalam satu bentuk ujaran atau lebih yang melibatkan dua pihak, yaitu penutur dan lawan tutur, dengan satu pokok tuturan, di dalam waktu, tempat, dan situasi tertentu (Chaer \& Agustina, 2010: 47).

Hymes dalam Chaer \& Agustina (2010:48-49) menjelaskan setidaknya peristiwa tutur harus memenuhi delapan komponen, yaitu: setting and scene; participants; ends : purpose and goal; act sequences; key : tone or spirit of act; instrumentalities; norms of interaction and interpretation; and genres.

Setting and scene berkenaan dengan waktu dan tempat tutur berlangsung, sedangkan scene mengacu pada situasi tempat dan waktu atau situasi psikologis pembicaraan. Participants adalah pihak-pihak yang terlibat dalam pertuturan, bisa pembicara dan pendengar, penyapa dan pesapa, atau pengirim dan penerima (pesan). Ends, merujuk pada maksud dan tujuan pertuturan. Act sequence, mengacu pada bentuk ujaran dan isi ujaran. Bentuk ujaran ini berkenaan dengan kata-kata yang digunakan, bagaimana penggunaannya, dan hubungan antara apa yang dikatakan dengan topik pembicaraan.

Sementara itu, Key, mengacu pada nada, cara dan semangat dimana suatu pesan disampaikan: dengan senang hati, dengan serius, dengan singkat, dengan sombong, dengan mengejek, dan sebagainya. Hal ini dapat juga ditunjukkan dengan gerak tubuh dan isyarat. Instrumentalities, mengacu pada jalur bahasa yang digunakan, seperti jalur lisan, tertulis, melalui telegraf atau telpon. Instrumentalities ini juga mengacu pada kode ujaran yang digunakan, seperti bahasa, dialek, fragma, atau register. Norm of interaction and interpretation, mengacu pada norma atau aturan dalam berinteraksi. Misalnya, yang berhubungan dengan cara berinterupsi, bertanya, dan sebahgainya. Juga mengacu pada norma penafsiran terhadap ujaran dari lawan bicara. Genre, mengacu pada jenis bentuk penyampaian, seperti narasi, puisi, pepatah, doa, dan sebagainya.

Peristiwa tutur dan tindak tutur merupakan satu kesatuan yang tidak bisa dipisahkan dalam arti keduanya saling melengkapi karena tindak tutur adalah bagian dari peristiwa tutur, dan peristiwa tutur adalah bagian dari situasi tutur. Pada situsi tertentu peristiwa tutur juga bisa berupa suatu pembicaraan yang disertai dengan tindakan, hal itu tetap termasuk 
peristiwa tutur, akan tetapi situasi yang berbeda tergantung tujuan tuturan yang ingin disamapaikan kepada lawan bicara. Hymes dalam Sumarsono (2012. 319). Melukiskan situasi tutur itu sebagai "situasi yang dikaitkan dengan (atau ditandai dengan tiadanya) tutur”. Konteks situasi semacam itu misalnya adalah upacara, peperangan, perburuan, makanmakan, memadu cinta. Situasi tutur tidaklah murni komunikatif: situasi itu mungkin terdiri dari peristiwa yang komunikatif dan peristiwa yang lain. Situasi tutur sendiri bukanlah kajian atau masalah kaidah wicara, tetapi dapat diacu oleh kaidah wicara sebagai konteks.

Tindak tutur merupakan perangkat terkecil dalam jenjang, yang merupakan derajat paling sederhana dan sekaligus paling sulit. paling sederhana karena merupakan "jenjang minimal dalam perangkat" analisis. paling sulit karena maknanya dalam etnografi komunikasi berbeda dari maknanya dalam pragmatik dan dalam fisafat, dan karena tindak tutur itu tidaklah cukup minimal berdasarkan menurut Hymes, tindak tutur harus dibedakan $\mathrm{m}$ enjadi kalimat, dan tidak harus diidentifikasikan dengan satuansatuan lain dalam gramatika (fonologi, morfologi). Adapun tindak tutur bisa mempunyai bentuk berupa kalimat panjang sekali, kalimat pendek, atau kalimat yang hanya terdiri dari sebuah morfem: "Keluar!", "Silahkan meninggalkan tempat ini!", "Sesuai dengan wewenang yang saya miliki, saya perintahkan kau untuk meninggalkan ruangan ini secepatnya!" semua adalah perintah. tindak tutur memperoleh statusnya baik dari konteks sosial maupun dari bentuk gramatikal dan intonasi. Hymes dalam Sumarsono (2012. 321).

\section{METODE PENELITIAN}

Penelitian ini merupakan penelitian kualitatif dengan pendekatan kajian Sosiolinguistik. Data berupa data verbal yang dikumpukan dari upacara selamatan laut masyarakat Desa Tanjung Luar Kecamatan Keruak Lombok. Informan penelitian ini adalah penutur asli masyarakat Tanjung Luar. Teknik pengumpulan data dalam penelitian ini adalah menggunakan metode simak (Pengamatan/Observasi) dan metode cakap (Wawancara). Teknik analisis data dalam penelitian ini menggunakan metode padan atau identity method. Kedua adalah metode agih atau distribusional method (Haugen, dalam Sudaryanto, 1993: 15).

\section{HASIL DAN PEMBAHASAN}

Peristiwa tutur dalam prosesi Selamatan Laut yang dikenal dengan istilah Nyelamak Dilau. Nyelamak Dilau merupakan tradisi yang terus-menerus 
dilakukan oleh masyarakat Tanjung Luar, yaitu satu kali dalam tiga tahun pada dasar pelaksanaanya. Dalam pergelaran acara ini membutuhkan seorang pemandu sebagai tolak ukur berhasil tidaknya acara tersebut. Untuk itulah tidak sembarang orang dapat berperan sebagai Sandro karena seorang Sandro adalah orang yang sangat dipercaya untuk bertindak sebagai Sandro semaksimal mungkin. Tradisi ini memang mendapatkan perhatian penuh dari pemerintah sebagai bentuk pemertahanan budaya supaya tidak mengalami keterancaman oleh masa modern saat ini.

Peristiwa tutur dalam prosesi Selamatan Laut ini, melibatkan beberapa orang dalam percakapan pada saat Nyelamak Dilau berlangsung, mulai dari awal pergelaran sampai pemotongan kepala kerbau yang tentu saja menimbulkan pro dan kontra dari masyarakat karena dianggap bid'ah atau paham kesyirikan. Adapun dari pihak lain sangat mendukung adanya Nyelamak Dilau karena takut akan keterancaman budaya yang selama ini menjadi warisan nenek moyang. Kemudian pada kondisi tertentu yang bisa berubah kapan saja, yang awalnya tenang menjadi sedikit gaduh disebabkab ada hal yang bersifat magis pada tempat pergelaran acara Nyelamak Dilau.

Lantunan lawas atau pitoto yang merupakan cerita atau sejarah yang dinyayikan dengan nada yang berbeda seperti kita mendengar orang nyinden. pitoto ini mempengaruhi pendengaran masyarakat, oleh sebab itu banyak diantara mereka mengalami kesurupan, dan untuk mengatasi hal tersebut tidaklah mudah, butuh waktu yang cukup lama untuk menyadarkannya. Tentu saja dengan rayuan-rayuan atau perkataan yang halus serta pemaksaan kepada Jin yang memasuki tubuh mereka. Perkataan sandro sangat penting pada saat acara itu karena ini membantu Jin keluar dari tubuh yang di rasuki. Iko-iko adalah irama lagu dari pitoto yang terdengar indah dan memiliki pesan magis.

\section{Awal Prosesi Berlangsung}

Sebelum menuju Laut tempat prosesi itu dilangsungkan, terlebih dahulu seorang mangku adat mempersiapkan peralatan yang dibutuhkan ketika prosesi itu, dan untuk mengadakan Nyelamak Dilau, masyarakat Tanjung Luar dan Sandro atau Mangku adat menggunakan seragam sesuai suku masing-masing untuk meminta izin kepada Si Pemilik Laut, agar Nyelamak Dilau segera untuk dilaksanakan. Sehingga terjadilah percakapan antara Sandro dan Dewa Laut, menurut kepercayaan masyarakat Tanjung Luar. Ketika seorang Sandro diam di tengah pembicaraannya, berarti permintaan izinnya masih belum disanggupi atau 
dipenuhi, dan harus menunggu beberapa hari atau beberapa jam tergantung cepat tidaknya Dewa Laut memberikan izin terkait Nyelamak Dilau. Percakapan yang biasa dikatakan, ketika Sandro meminta izin, seperti di bawah ini:

Percakapan pada pembukaan acara Nyelamak Dilau yang dilakukan oleh Sandro dengan penghuni laut (Dewa Laut).

Sandro : : Mak bucu lahak? Mejin ko! Ma terima majinasami (bagaimana! Apa kamu menerima kami).

Dewa Laut : Untuk perkataan dari Dewa Laut tidak bisa didengar, yang tahu dan mendengar adalah Sandro.

Sandro $\quad$ : Lamun kau teqa lamun kau darat! Kaming kalopah, suram anung rajane. (aku tidak suka menerima pesuruh dan perintah, kalau rajamu rajamu yang suruh. Panggil rajamu!)

Pesuruh Dewa : Yo (ya).

Sandro : Selamaq teqa Nyelamak Dilau. (selamat datang di acara Nyelamak Dilau) Ketika raja Laut atau Dewa Laut datang.
Sandro : Panangih ai kok ? (darimana kamu?). sandro menanyakan asal roh.

\section{Waktu Tikolok Berlangsung}

Tikolok atau proses pemotongan Kepala Kerbau yang akan ditaruh di Dasar Laut sebagai persembahan atau sebagai bentuk rasa syukur masyarakat Tanjung Luar terhadap kekayaan laut yang terbilang bagus. Tikolok dalam prosesi Nyelamak Dilau adalah hal yang paling ditunggu-tunggu oleh masyarakat Tanjung Luar karena mengambil darah kepala kerbau akan menghindarkan masyarakat Tanjung Luar dari penyakit, dan bagi mereka darah Kepala Kerbau berfungsi sebagai obat dari penyakit jenis apapun.

Napupok (berunding), dilakukan sebelum tikolok, yang dimana bahwa masyarakat berunding untuk menaruh Kepala Kerbau pada posisi yang tepat. "nasambele Kerbau itu, bekadali di pasaq karaki. Nadumoh udajumoh nadi lanti me." (kerbau di potong kepalanya , biar cepat dimaksuukkan ke rakit. Pengukusan dengan menggunakan Menyan). Saloh nyanyaloh napore kadilauk jok segare nambak tikolok Kerbau iru. Bone-bone memong tebeak di kaling min telu batu iru. Buk nene di palagak tikolok kerbau iru. (pagi-pagi sekali pergi ke Laut untuk membuang Kepala Kerbau di Laut. Semua ikut ke Laut, pergi menyaksikan Nyelamak 
Dilau. Setelah sampai di tengah Laut Kepala Kerbau di buang). Adapun di bawah ini kalimat-kalimat yang sering digunakan saat tikolok:

Nane nadibue Kerbau iru parupuk min telu. (silahkan keliling Kerbau ke Desa Tanjung Luar).

$>$ Palalung yang penting karua. (pelan-pelan yang penting benar).

> Nginai para aha jogek Nyelamak Dilau, dangko lek aha man Dilau. (kenapa orang banyak kesurupan ketika Selamatan Laut karena dirasuki oleh penghuni Laut).

Tikolok dilakukan setelah kegiatan sebelumnya sudah terlaksana, yaitu; pengelilingan Kerbau selama tiga kali berturut-turut dari tempat prosesi sampai pemukiman warga, barulah Kepala Kerbau bisa dipotong. Pengantaran atau penaruhan Kepala Kerbau diiringi dengan tujuh Bone perempuan dan laki-laki yang masih terjaga kesuciannya (Perawan dan Perjaka). Selain itu juga Gendang Beleq juga ikut mengiringi prosesi Nyelamak Dilau. Diantara semua kegiatan yang dilaksanakan dalam prosesi ini, Tikolok merupakan kegiatan yang paling berkesan bagi masyarakat Tanjung Luar, dan tidak sedikit orang yang mengalami kesurupan, karena sebagian dari mereka tidak dapat mengontrol dirinya, sehingga terjadilah kesurupan. Beberapa dari Masyarakat Tanjung Luar mulai menunjukkan sikap tidak wajar, seperti mata yang terlihat kosong, bicara yang tidak terkontrol, pingsan, tubuh yang bergetar, bergoyang dan lain-lain.

Mata Kosong : Pertanda bahwa Jin sudah mulai merasuki tubuh.

Bicara Tidak Terkontrol : Tubuhnya Sudah Di Rasuki Jin.

Tubuh Bergetar : Proses Masuknya Jin.

Bergoyang : Tubuh Sudah Di Kuasai.

Pingsan : Masuk Dan Keluarnya Jin.

Di bawah ini, adalah bentuk perkataan yang diajukan Sandro, pada saat mengobati orang yang kesurupan :

a) Ai niak lolo atau molekne kita lolo (Ayo pulang Datu). Dalam bahasa Bajaunya.

b) Adang karo (Ayo pulang). Dalam bahasa Bugisnya.

c) Adi suknobi arung (Ayo pulang Datu). Dalam bahasa Mandarnya.

d) Punna ngalase bicaraneye, ne ngalase tajem poleh (Kalau sudah selsai bicara, ayo pulang kenapa harus menunggu). Dalam bahasa Makassarnya.

\section{Pitoto Dan Iko-Iko}


Pitoto yang selalu dipasangkan dengan Iko-iko, merupakan suatu hal yang wajib dalam Nyelamak Dilau. Pitoto dan Iko-Iko memberikan pengaruh yang sangat besar pada masyarakat Tanjung Luar, karena Pitoto adalah sebuah cerita yang dilantunkan yang terdengar tak biasa, ada kengerian maupun unsur magis, sehingga memicu timbulnya kesurupan. Selain itu juga Pitoto dan Iku-Iku dapat menjadi penyembuh untuk penyakit yang bersifat batin, seperti gila, rasa takut dan lain-lain, namun pitoto juga dapat memicu terjadinya hal-hal yang tak diinginkan seperti pingsan dan sebagainya.

Lagu Pitoto yang dikenal sebagai bahasa pengantar dalam upacara Nyelamak Dilau berisi cerita asal-usul Tanjung Luar maupun cerita lain. Pitoto selalu digandengkan dengan iko-iko sebagai pengiring pada prosesi tersebut.

\section{SIMPULAN}

\section{Bentuk Peristiwa Tutur Dalam Prosesi Selamatan Laut}

Nyelamk Dilau atau Selamatan Laut dilangsungkan terlebih dahulu masyarakat setempat berencana atau berunding yang disebut Napupok. Napupok dilakukan tidak hanya pada saat tikolok, tetapi Napupok dilakukan sebelum prosesi Nyelamak Dilau dilangsungkan. Napupok (berunding) merupakan peristiwa tutur karena memenuhi beberpa komponen peristiwa tutur, diantaranya; participants, merupakan pendengar dan pembicara atau orang yang terlibat dalam tuturan. Instrumentalities, mengacu pada jalur bahasa yang digunakan. Bahasa yang digunakan adalah bahasa lisan dengan menggunakan bahasa Bajau. Ends, yang biasa disebut dengan tujuan tuturan. Napupok memiliki tujuan untuk menentukan atau memutuskan kapan Nyelamk Dilau dan Tikolok dilangsungkan, dan lain-lain.

Setelah Napupok dilakukan, masyarakat setempat akan pergi meminta izin kepada Dewa Laut terkait Prosesi Nyelamak Dilau yang akan dilangsungkan dalam waktu dekat ini. Adapun terkait permintaan izin prosesi tersebut terjadi percakapan antar Dewa Laut dan Sandro sehingga ada tawar-menawar antara keduanya. Percakapan yang dilakukan Dewa Laut dan Sandro bisa dilihat di hasil penelitian. Percakapan tersebut termasuk dalam peristiwa tutur karena memenuhi beberpa komponen peristiwa tutur, yaitu; melibatkan beberapa orang dalam percakapan, yaitu masyarakat, Sandro dan Pesuruh Dewa Laut. Pada dasarnya untuk percakpan Dewa Laut dan Pesuruh Laut secara akal sehat tidak bisa didengar, namun yang mengetahui isi dan jawaban dari percakapan tersebut adalah Sandro. 
Namun sekalipun kita tidak mengtahui apa isi dari percakapan Dewa Laut dan Sandro, namun kita bisa mengetahui jawaban tersebut dari bahasa tubuh yang digunakan, dan nada suara yang biasa disebut Key dan Genre.

\section{Bentuk Tindak Tutur Dalam Prosesi}

\section{Selamtan Laut}

Tikolok berlangsung, yang biasa ditandai dengan banyak hal salah satunya banyak orang yang mengalami kesurupan, maupun kegiatan Tikolok terbilang sakral sebagai kegiatan inti waktu prosesi Nyelamak Dilau digelar. Ada beberapa percakapan yang berupa perintah seperti di bawah ini:

"Ai niak lolo atau molekne kita lolo (ayo pulang Datu)." Percakapan ini tergolong tindak tutur lokusi karena menimbulkan perintah, yaitu perintah kepada Jin yang masuk kedalam tubuh orang yang kesurupan agar keluar. Adapun dalam Tikolok sampai prosesi selsai, Sandro perempuan menggunakan bahasa isyarat seperti tangan menyilang bermakna ada hal yang tidak boleh dilakukan. Namun apabila Sandro menunujuk kesuatu tempat berarti hal itu bermakna benda atau orang kesurupan bisa diletakan di tempat tersebut. Hal tersebut tergolong dalam klasifikasi tindak tutur secara umum, yaitu direktif yang merupakan jenis tidak tutur yang dipergunakan untuk menyuruh orang lain untuk melakukan suatu hal.

\section{DAFTAR PUSTAKA}

Chaer, Abdul \& Agustina Leonie, 2010. Sosiolinguistik Perkenalan Awal. Jakarta: Rineka Cipta.

Sugiyono. 2014. Metode Penelitian Kuantitatif, Kualitatif, dan $R \& D$. Bandung: Alfabeta.

Mahsun. 2007. Metode Penelitian Bahasa: Tahapan Strategi, Metode, dan Tekniknya. Jakarta: PT Raja Grafindo Persada.

Sumarsono. 2012. Sosiolinguistik. Yogyakarta: Pustaka Pelajar.

Nadar. 2009. Pragmatik \& Penelitian Pragmatik. Yogyakarta: Graha Ilmu.

Muhammad. 2014. Metode Penelitian Bahasa. Jogjakarta: Ar-Ruzz Media.

Yule, George, 2006. Pragmatik. Yogyakarta: Pustaka Pelajar. 